\title{
Multivariate Methods for Evaluating the Efficiency of Electrodialytic Removal of Heavy Metals from Polluted Harbour Sediments
}

\author{
Kristine Bondo Pedersen ${ }^{\mathrm{a}}$, Gunvor M. Kirkelund ${ }^{\mathrm{b}}$, Lisbeth M. Ottosen ${ }^{\mathrm{b}}$, Pernille E. Jensen ${ }^{\mathrm{b}}$ and Tore \\ Lejon $^{* a}$ \\ *Corresponding author: e-mail tore.lejon@uit.no; tel. +47 77644736 \\ ${ }^{a}$ Department of Chemistry, UiT The Arctic University of Norway, Postbox 6050 Langnes, N-9037 \\ Troms $\varnothing$, Norway. \\ ${ }^{\mathrm{b}}$ Arctic Technology Centre, Department of Civil Engineering, Technical University of Denmark, \\ Building 118, 2800 Lyngby, Denmark
}

\begin{abstract}
:
Chemometrics was used to develop a multivariate model based on 46 previously reported electrodialytic remediation experiments (EDR) of five different harbour sediments. The model predicted final concentrations of $\mathrm{Cd}, \mathrm{Cu}, \mathrm{Pb}$ and $\mathrm{Zn}$ as a function of current density, remediation time, stirring rate, dry/wet sediment, cell set-up as well as sediment properties. Evaluation of the model showed that remediation time and current density had the highest comparative influence on the clean-up levels. Individual models for each heavy metal showed variance in the variable importance, indicating that the targeted heavy metals were bound to different sediment fractions.

Based on the results, a PLS model was used to design five new EDR experiments of a sixth sediment to achieve specified clean-up levels of $\mathrm{Cu}$ and $\mathrm{Pb}$. The removal efficiencies were up to $82 \%$ for $\mathrm{Cu}$ and $87 \%$ for $\mathrm{Pb}$ and the targeted clean-up levels were met in four out of five experiments. The clean-up levels were better than predicted by the model, which could hence be used for predicting an approximate remediation strategy; the modelling power will however improve with more data included.
\end{abstract}

Keywords: Harbour sediments, electrodialytic remediation, electrokinetic remediation, heavy metals, multivariate modelling

\section{Introduction}

Harbour sediments have been exposed to a wide variety of pollutants caused by decades of polluting human activities in the harbours as well as on adjacent land. The need for management or treatment actions arises either through governmental acts to decrease the risks for human health and the environment; or through the development of harbours in which contact with, or removal of, polluted sediments is inevitable, e.g. when increasing navigational depths. Existing remediation technologies include: dredging and disposal on land or in deep sea disposal sites; capping polluted sediments by in-situ covering with non-polluted material; dredging, solidification and stabilisation (STSO) in which polluted sediments are incorporated in construction materials, for instance in harbour foundations. Historically there has been limited focus on treatment strategies for dredged sediments [1]. However, with the general European effort on moving towards more sustainable societies, in which the amount of waste is reduced, along with considerations of minimising the pollution legacy for 
future generations, more emphasis on identifying and developing methods for removing pollutants from dredged polluted sediments prior to recycling these may be expected in the future.

Electrodialytic remediation (EDR) provides a method for removing heavy metals from different polluted materials such as soil, wood, fly ash, sewage sludge and harbour sediments [2-6]. The principle of EDR is to apply an electric field to the polluted material, initiating processes to acidify the material with subsequent desorption, mobilisation and ultimately removal of the heavy metals from the material.

The EDR technology for removal of heavy metals from polluted materials was developed at the Technical University of Denmark in the early 1990s. The method is based on the principles of electrokinetic remediation, in which an electric field is applied to the material, thus mobilising charged particles. A low level current (order of $\mathrm{mA} / \mathrm{cm}^{2}$ of the cross sectional area between the electrodes) is applied and the fluid in the suspension acts as the conductive medium. Transport processes are dominated by electromigration, i.e. the transport of ions and ionic complexes in the (pore) fluid of the polluted material [7-9] (figure 1).

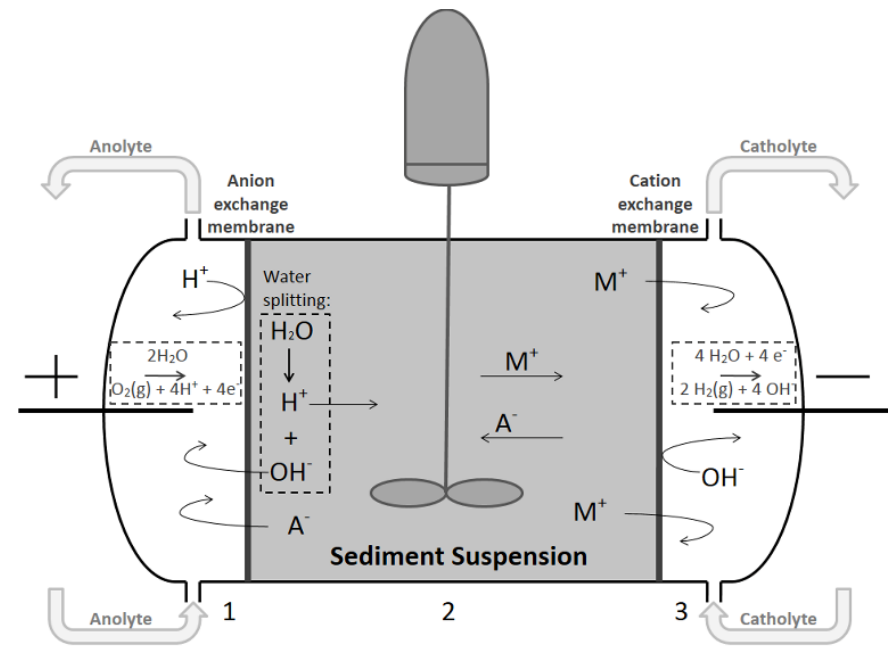

Figure 1 Electrodialytic cell set-up.

In EDR, ion exchange membranes separate the suspended material from the electrodes and circulating electrolytes, simultaneously controlling the transport of ions between the sediment suspension and the electrolytes [2]. The ion exchange membranes prevent the $\mathrm{H}^{+}$and $\mathrm{OH}^{-}$ions produced in the electrolysis reactions at the anode and cathode, respectively, from entering the suspension, while at the same time ensuring that adjacent anions and cations are transported across the anion- and cation exchange membranes.

An acidic front is formed in the suspension, mainly due to water splitting at the anion exchange membrane, producing $\mathrm{H}^{+}$and $\mathrm{OH}^{-}$ions directly into the polluted material [10]. The $\mathrm{OH}^{-}$ions produced are transported across the anion exchange membrane to the anolyte and the protons produced form the acidic front advance towards the cathode. The acidic conditions desorb cations adsorbed to particles in the sediment, subsequently transporting them to the cathode by electromigration. The advancement of the acidic front with the desorbed cations depends on the physical and chemical properties of the polluted medium. A high buffering capacity will for instance slow the acidification, as will high contents of organic species and salts [7-9]. 
Several EDR studies of polluted harbour sediments have been conducted on laboratory scale using an electrodialytic cell (figure 1 ), resulting in final concentrations of the targeted heavy metals $(\mathrm{Cd}, \mathrm{Cu}, \mathrm{Pb}$ and $\mathrm{Zn}$ ) well below levels considered hazardous to human health and the environment according to national guidelines and recommended values from OSPAR [11-20]. Clean-up levels and efficiencies were found to depend on sediment properties, liquid-to-solid ratio (L/S) of the sediment suspension, current density and remediation time $[12,13,17]$. In addition, an experimental set-up with a stirred sediment suspension was found to be significantly more efficient than a stationary set-up [14, 18].

Mathematical simulation/modelling can be used for predicting clean-up levels for a specific sediment under given experimental conditions. Physico-chemical models for contaminant transport during EDR/EKR (electrokinetic remediation) have been developed with good correlations between predicted and experimental values for soil [21], brick [22] and fly ash [23] over limited experimental domains, whereas larger variations between simulations and observations were reported for longer remediation times [21].Though the modelling has led to better understanding of the EDR/EKR processes, it has not been used for predicting experimental conditions for achieving specific remediation goals of new samples/materials.

Statistical analyses of reported experimental results can be used to determine trends and correlations in a system without regarding the processes in the system, i.e. assessing the possible relations between the inputs and outputs. In traditional statistical analyses, such as multiple regression analyses, input variables are assumed to be independent, which can lead to biased results if variables in fact are correlated. Variables such as current density and remediation time cannot be assumed to be independent [24], but Principal Component Analysis (PCA) and Projections onto Latent Structures (PLS) cope with collinearity between variables and in addition provide plots of the data compressed to fewer dimensions than the original dataset [25].

PCA is a tool for visualising the differences and similarities in large data sets by calculating principal components. These are mutually orthogonal vectors that represent independent and uncorrelated variation of the initial descriptors, leading to correlated descriptors being described by the same principal component. Score plots are obtained by projecting the original data onto the calculated orthogonal principal component vectors. The systematic variation in the data set can hence be simplified by using fewer new descriptors (scores) than the original number of variables and this simplification is done without loss of systematic information [25].

The influence of each original descriptor to the principal component is reflected by the loadings. Thus, descriptors which have a strong contribution to the variation depicted in the score plot are found far from the origin in the loading plot. Positively correlated descriptors are projected close to each other, while negatively correlated descriptors are projected opposite each other with respect to the origin [25].

In environmental studies PCA has been used to obtain information on pollutant distribution in sediment/soil/water and possible clustering trends related to sediment properties, which in some cases have been used to assess sources of pollution[26-29]. In a study by Filgueiras et al., PCA plots of the different fractions of the sediments (exchangeable, reducible, oxidisable and residual) were used to assess heavy metal binding and pollutant sources in the sediment and the authors were for instance able to relate $\mathrm{Cu}$ and $\mathrm{Pb}$ to the organic matter, suggesting urban origin [29]. 
PLS is a multivariate method for modelling quantitative relationships between a descriptor matrix, $X$ and a response matrix, Y. An established quantitative model can then be used to compute expected responses by entering new data into the $X$ matrix $[25,30]$.

Since PLS is based on projections, it is possible to have more variables than number of experiments. Object points in each of the $X$ and $Y$ matrices are projected down to a PLS component. For each PLS dimension the PLS scores of the Y-matrix has a maximum correlation to the scores of the X-matrix. New PLS components are iteratively introduced until the systematic variation in the $Y$-matrix has been exhausted [25, 30-32].

$\mathrm{R} 2 \mathrm{Y}$ is introduced as a measure of the fraction of the $\mathrm{Y}$ matrix explained by the model and the predictive power, Q2 is an estimate of the reliability of the model calculated by cross-validation.

Variable Importance in the projection (VIP) plots present the importance of each parameter in the model with respect to its correlation to all the responses $(\mathrm{Y})$ and to the projection $(\mathrm{X})$. VIP plots can hence reflect the relative importance of the model parameters to each other and parameters with VIP values above 1 are considered relevant for explaining the responses.

While PLS has been extensively used in organic synthesis for instance to eliminate/minimise the production of undesirable byproducts or predicting optimum synthesis conditions [25] the method has not yet found use in remediation studies. Examples of PLS use include identifying natural/anthropogenic sources in ground water [33] and identifying important factors for production of toxic PCDDs and PCDFs in waste combustion [34]. In remediation of harbour sediments PLS could be a useful tool for meeting challenges in developing site-specific remediation strategies, taking into regard the complexity in sediment composition, remediation objectives and operational limits.

The objective of this study was to demonstrate PLS as a tool for evaluating EDR of harbour sediments. This was done by model development and assessment of previously conducted and reported EDR experiments, followed by model prediction of an EDR test scheme for new sediment in order to evaluate the correlation between the model predictions and the observed experimental results.

\section{Materials and Methods}

\subsection{Calculation methods}

In this study SimcaP11 Software was used for PCA of sediment properties and PLS modelling based on 46 experiments from seven EDR studies (table 1). The 46 experiments were conducted in accordance with different objectives and do hence not cover a perfect multivariate design, none the less, as is apparent from table 1, they were conducted within same/similar experimental domains and have strong indicative value.

To make a more comprehensive assessment of the comparative influences of the different sediments and the experimental variables, the $\mathrm{X}$ matrix consisted of sediment properties in addition to 6 experimental variables. The sediment properties included carbonate, organic matter, $p H$, conductivity, grain size below $<63 \mu \mathrm{m}$, chloride and selected metals in the sediment matrix $(\mathrm{Al}, \mathrm{Fe}, \mathrm{K}$, 
$\mathrm{Mn}, \mathrm{Na}$ ). The continuous experimental variables included remediation time, current density, $L / S$ and stirring rate. Each of the two discrete experimental variables (two EDR cell set-ups based on 5 compartments (A) or 3 compartments (B) [14] as well as applying dry or wet sediment) were arbitrarily set to 1 or -1 . The $Y$ matrix consisted of the final concentrations of the four heavy metals $\mathrm{Cd}, \mathrm{Cu}, \mathrm{Pb}$ and $\mathrm{Zn}$. 
Table 1: Data review of studies used in the PLS model

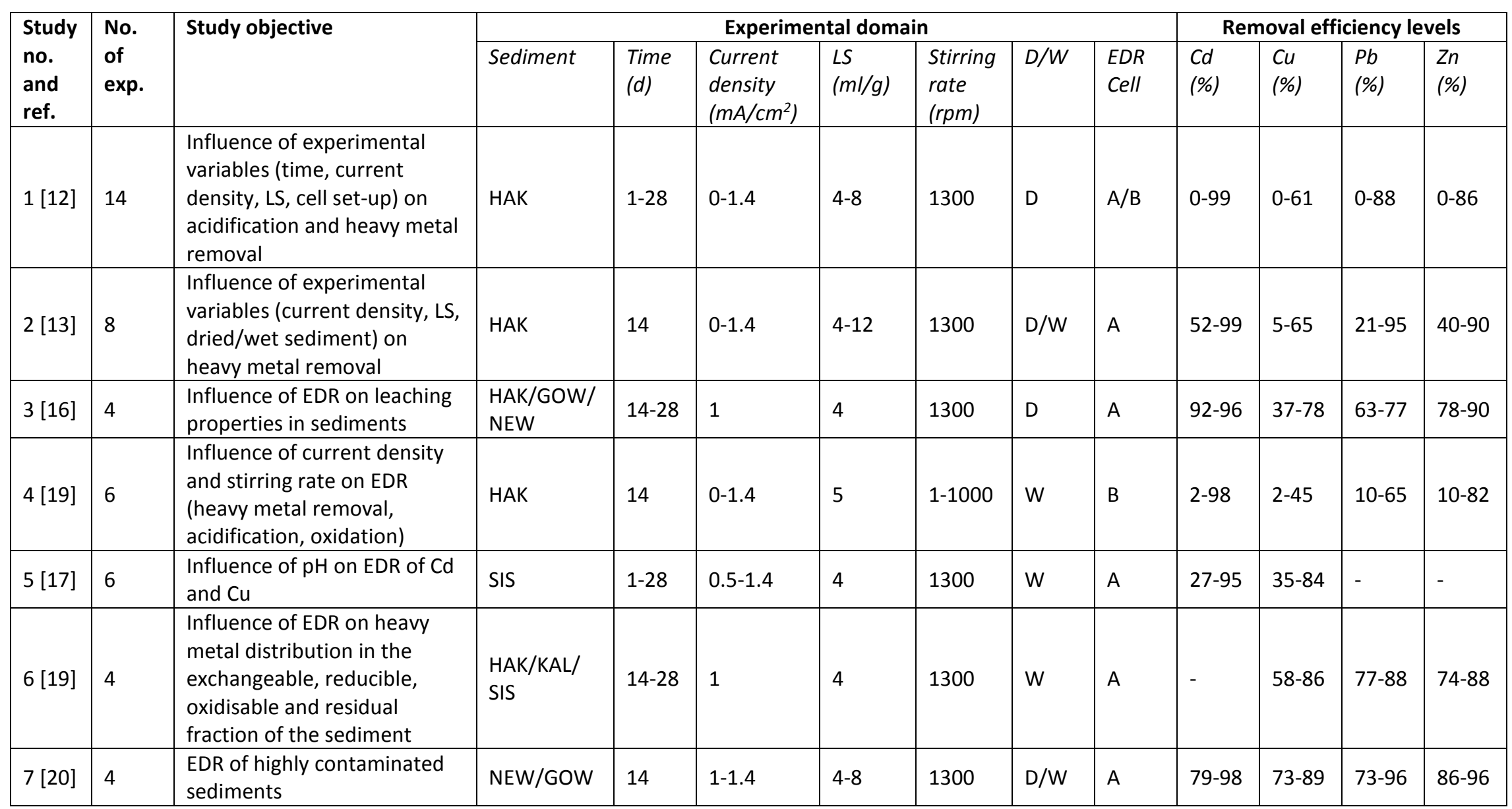

$D / W:$ Dry/wet sediment used in the EDR

EDR cell set-ups: A (5 compartments); B (3 compartments)

HAK - Sediments from Haakonsvern, Norway

GOW - Sediments from Gowanas Canal, USA

NEW - Sediments from Newport, USA

SIS - Sediments from Sisimiut, Greenland 


\subsection{Experimental sediments}

Sediments from Hammerfest, Norway and Sisimiut, Greenland were sampled from the top $10 \mathrm{~cm}$ of the seabed using a Van Veen grab. Sediments were sampled at different locations in the harbours based on potential land-based pollution sources giving 5 sediments from Hammerfest and 4 sediments from Sisimiut. The sediments were kept cool during transport and were stored in a freezer until analysed or treated.

\subsection{Analytical}

Unless otherwise stated below the sediments were dried at $105^{\circ} \mathrm{C}$ before the analysis. All analyses were made in triplicate.

Major elements and heavy metal concentrations ( $\mathrm{Al}, \mathrm{Ca}, \mathrm{Fe}, \mathrm{K}, \mathrm{Mn}, \mathrm{Na}, \mathrm{Cd}, \mathrm{Cu}, \mathrm{Pb}, \mathrm{Zn}$ ) were measured based on digestion (Norwegian standard NS4770). Dried sediment (1.0g) and $\mathrm{HNO}_{3}(9 \mathrm{M}$, $20 \mathrm{~mL}$ ) were autoclaved $\left(200 \mathrm{kPa}, 120^{\circ} \mathrm{C}, 30\right.$ minutes). Solid particles were subsequently removed by vacuum filtration through a $0.45 \mu \mathrm{m}$ filter and the liquid was diluted to $100 \mathrm{~mL}$. Metal concentrations in the liquid were measured by Inductively Coupled Plasma (ICP-OES).

Chloride content was measured by agitating sediment $(10 \mathrm{~g})$ dried at $40^{\circ} \mathrm{C}$ with micropore water $(40 \mathrm{~mL})$ for 20 hours. Solid particles were removed by $0.45 \mu \mathrm{m}$ vacuum filtration and the chloride concentration was measured by ion chromatography.

Carbonate content was measured by treating dried sediment $(0.5-5.0 \mathrm{~g})$ with $\mathrm{HCl}(3 \mathrm{M} ; 20 \mathrm{~mL})$ and the developed $\mathrm{CO}_{2}$ was measured volumetrically in a Scheibler apparatus, calibrated with $\mathrm{CaCO}_{3}$.

Organic content was based on loss of ignition of dried sediment $(2.5 \mathrm{~g})$ being heated at $550^{\circ} \mathrm{C}$ for an hour.

$p H(K C l)$. Dried sediment $(5.0 \mathrm{~g})$ was agitated with $\mathrm{KCl}(1 \mathrm{M}, 12.5 \mathrm{~mL})$ for an hour and $\mathrm{pH}$ was subsequently measured using a radiometric analytical electrode.

Conductivity. Dried sediment $(5.0 \mathrm{~g})$ was agitated with distilled water $(25 \mathrm{~mL})$ for an hour and the conductivity was subsequently measured using a radiometric analytical electrode.

Wet and dry sieving. Wet sediment $(75 \mathrm{~g})$, distilled water $(350 \mathrm{~mL})$ and $\mathrm{Na}_{4} \mathrm{P}_{2} \mathrm{O}_{7} \cdot 10 \mathrm{H}_{2} \mathrm{O}(0.1 \mathrm{M}, 10 \mathrm{~mL})$ was agitated for 24 hours. The slurry was subsequently sieved through a $63 \mu \mathrm{m}$ sieve to determine the fraction above and below $63 \mu \mathrm{m}$.

\subsection{EDR experiments}

The electrodialytical cell set-up is illustrated in figure 1. The cell was manufactured from Plexiglas and the dimensions were as follows: electrolyte compartment length $3.5 \mathrm{~cm}$, centre compartment length $10 \mathrm{~cm}$ and inner diameter $8 \mathrm{~cm}$ in all three compartments. Ion exchange membranes from lonics (anion exchange membrane 204 SZRA B02249C and cation exchange membrane CR67 HUY N12116B) separated the electrolyte compartments from the centre compartment. The electrolyte used in both electrolyte compartments was $\mathrm{NaNO}_{3}(0.01 \mathrm{M})$ adjusted by $\mathrm{HNO}_{3}(7 \mathrm{M})$ to $\mathrm{pH} 2$. Electrolyte $(500 \mathrm{~mL})$ was circulated in each electrolyte compartment via Pan World pumps with a flow rate of $2.6 \mathrm{~mL} / \mathrm{min}$. Platinum coated titanium electrodes were used in each electrolyte compartment and a power supply 
(Hewlett Packard E3612A) maintained a constant DC current. The sediment suspension was stirred by a RW11 Basic lab-egg (IKA 2830001) with a stirrer consisting of plastic flaps $(4 \mathrm{~cm} \times 0.5 \mathrm{~cm})$ fastened to a glass rod.

After the EDR experiments the sediment suspensions were filtered through a gravitational filter and the heavy metal concentration in both the suspension liquid and solids were measured. The stirrer, membranes and electrodes were rinsed in $5 \mathrm{M} \mathrm{HNO}_{3}$ overnight and the heavy metal concentrations in the rinsing liquids along with the electrolyte liquids were measured by ICP.

Sediments from Hammerfest were used in the EDR experiments, which were conducted within the experimental domains of the 7 previous studies (table 1 ) focusing on $\mathrm{Cd}, \mathrm{Cu}, \mathrm{Pb}$ and $\mathrm{Zn}$, as in the previous studies. Five EDR experiments were performed at remediation time range of 3 to 20 days and a current density range of $0.04-0.52 \mathrm{~mA} / \mathrm{cm}^{2}$. The $L / S$ of the sediment suspension was $6 \mathrm{ml} / \mathrm{g}$ and the stirring rate was 1,300 rpm. The experimental variables are given in Table 2.

Table 2: Experimental variables in the EDR experiments

\begin{tabular}{|l|l|l|}
\hline Experiment id & Time (d) & $\begin{array}{l}\text { Current density } \\
\left(\mathbf{m A} / \mathbf{c m}^{\mathbf{2}}\right)\end{array}$ \\
\hline 1 & 20 & 0.20 \\
\hline 2 & 7 & 0.20 \\
\hline 3 & 13.5 & 0.36 \\
\hline 4 & 3 & 0.52 \\
\hline 5 & 20 & 0.52 \\
\hline
\end{tabular}

\section{Results and Discussion}

\subsection{PLS modelling of previous results}

The PLS modelling based on the experiments listed in table 1, resulted in a model with a correlation factor R2Y of 0.71 and a predictive power, Q2 of 0.50 ; the latter indicating a fairly stable model. Since the model showed consistently good correlation factors and predictive power values for each of the heavy metals ( $\mathrm{Cd}, \mathrm{Cu}, \mathrm{Pb}$ and $\mathrm{Zn}$ ) in the $\mathrm{Y}$-matrix; and had no statistical outliers, the model was used for assessing the comparative importance of the $\mathrm{X}$ matrix variables, i.e. the sediment properties as well as the experimental variables.

A VIP plot was used for analysing the importance of the parameters in the model and the VIP values are summarised in table 3 , revealing that the experimental variables current density and remediation time have VIP values above 1 and are in addition significantly higher than the other values.

The VIP values of variables related to the sediment properties are all between 0.5 and 1.0 (table 3 ) indicating moderate influence on the model. In addition, it should also be noted that the $\mathrm{X}$ matrix covers a vast amount of variables with the potential of confounding effects not being expressed by the model, so the sediment properties should not be disregarded as having no effect on the remediation.

$\mathrm{Cu}, \mathrm{Pb}$ and $\mathrm{Zn}$ have VIP values above 1, which is assessed as being related to the large variation in initial concentrations rather than the heavy metals themselves influencing the model. 
Table 3: VIP values of the variables in the X-matrix. Values above 1 are accentuated in bold.

\begin{tabular}{|l|l|l|l|}
\hline $\begin{array}{l}\text { VIP values of } \\
\text { experimental variables }\end{array}$ & $\begin{array}{l}\text { VIP values of } \\
\text { sediment properties }\end{array}$ & $\begin{array}{l}\text { VIP values of major } \\
\text { elements in the } \\
\text { sediments }\end{array}$ & $\begin{array}{l}\text { VIP values of heavy } \\
\text { metals in the sediments }\end{array}$ \\
\hline $\mathbf{1 . 9 3}$ Current density & $0.91 \mathrm{pH}$ & $0.90 \mathrm{Al}$ & $\mathbf{1 . 3 3} \mathrm{Cu}$ \\
$\mathbf{1 . 7 9}$ Time & 0.91 Carbonate & $0.91 \mathrm{Fe}$ & $\mathbf{1 . 1 0} \mathrm{Pb}$ \\
1.00 LS & 0.91 Conductivity & $0.91 \mathrm{Ca}$ & $\mathbf{1 . 1 9} \mathrm{Zn}$ \\
0.85 Cell set-up & 0.88 Grain size $<63 \mu \mathrm{m}(\%)$ & $0.90 \mathrm{~K}$ & $0.97 \mathrm{Cd}$ \\
0.42 Stirring rate & 0.70 Organic matter & $0.90 \mathrm{Mg}$ & $0.87 \mathrm{Ni}$ \\
0.41 Dried/wet & & $0.88 \mathrm{Na}$ & $0.77 \mathrm{As}$ \\
\hline
\end{tabular}

Modelling of $\mathrm{Cd}, \mathrm{Cu}, \mathrm{Pb}$ and $\mathrm{Zn}$ was done individually in order to assess the similarities and differences in the comparative importance of the variables. The resulting models had correlation factors in the range $0.69-0.74$ and prediction power values in the range $0.46-0.57$ signifying good and fairly stable models.

Table 4 summarises the results of the VIP plots for each heavy metal model, including assessments of whether significant variables in the model have a positive or negative influence on the remediation process.

The VIP values for current density and remediation time were above 1 for all heavy metals, thus strongly influencing the remediation process in line with the results achieved from modelling all the heavy metals in one model (table 3). There are however differences in the influence of the other experimental variables depending on the specific heavy metal; most noticeable for the variables $L / S$ and cell set-up. These two variables influence the models of $\mathrm{Cd}$ and $\mathrm{Pb}$ to a much higher degree than for $\mathrm{Cu}$ and $\mathrm{Zn}$. This could indicate that a relatively larger fraction of $\mathrm{Cd}$ and $\mathrm{Pb}$, is present in the exchangeable fraction of the sediment, e.g. as soluble salts.

A previous study indicated that the stirring rate influenced EDR of $\mathrm{Cu}$ and $\mathrm{Pb}$ [18] but these results were based on few experiments of one sediment and could not be verified in this study. In order to get a more comprehensive understanding of the influence of the stirring rate, the model should be extended with further investigations of a larger range of sediments.

Previous studies of changes in sediment during leaching [35] and EDR [19] showed that drying sediments altered the metal distribution in the different fractions of the sediment due to oxidation processes. Since applying dry or wet sediment does not appear to influence the model, which is in line with a previous EDR study [13], this indicates that the EDR process is more significant to the availability of the metals than the drying process or that stirring the sediment suspension outweighs any initial differences in leachability of the sediments.

Carbonate was found to influence the model of $\mathrm{Cu}$, implying that $\mathrm{Cu}$ was bound to carbonates in the sediment to a higher degree than other heavy metals and was mobilised in the initial acidification phase of EDR. The simultaneous influence of $p H$ could be due to the fact that the sediments with the higher carbonate contents also have higher $\mathrm{pH}$ values within the $\mathrm{X}$-matrix ranges. It is hence not clear whether the indicated higher influence of $\mathrm{pH}$ on the removal of $\mathrm{Cu}$ is directly related to $\mathrm{pH}$ or due to the similar variation of carbonate content in the sediments. 
The silt and clay fractions (grain size $<63 \mu \mathrm{m}$ ) in the sediments influence the removal of $\mathrm{Zn}$. Less silt and clay in the sediment leads to a lower final concentration indicating that $\mathrm{Zn}$ is differently bound in the sediment than the other heavy metals. This is in line with earlier results where it was shown that a larger fraction of $\mathrm{Zn}$ was related to the exchangeable fraction of the sediment [19].

Table 4: The influence of selected variables on the final concentrations of $\mathrm{Cd}, \mathrm{Cu}, \mathrm{Pb}$ and $\mathrm{Zn}$ after EDR treatment. Low final concentrations are achieved by high (+) or low values (-) of the given variables. 'Low' indicates low influence and covers variables with VIP values below 1 .

\begin{tabular}{|c|c|c|c|c|}
\hline & $\mathrm{Cd}$ & $\mathrm{Cu}$ & $\mathrm{Pb}$ & $\mathrm{Zn}$ \\
\hline \multicolumn{5}{|c|}{ Experimental variables } \\
\hline Current density & + & + & + & + \\
\hline Remediation time & + & + & + & + \\
\hline LS & + & Low & + & Low \\
\hline Stirring rate & Low & Low & Low & Low \\
\hline Cell set-up & 5 compartments & Low & 5 compartments & Low \\
\hline Dried/wet sediment & Low & Low & Low & Low \\
\hline \multicolumn{5}{|l|}{ Sediment properties } \\
\hline $\mathrm{pH}$ & Low & + & Low & Low \\
\hline Carbonate & Low & + & Low & Low \\
\hline Grain size $<63 \mu g$ & Low & Low & Low & - \\
\hline \multicolumn{5}{|l|}{ Metals/salts } \\
\hline $\mathrm{Al}, \mathrm{Fe}$ & Low & Low & - & - \\
\hline $\mathrm{Ca}, \mathrm{K}, \mathrm{Na}$ & Low & Low & - & - \\
\hline $\mathrm{Mg}$ & Low & Low & - & - \\
\hline \multicolumn{5}{|l|}{ Heavy metals } \\
\hline $\mathrm{Cu}$ & Low & - & Low & Low \\
\hline $\mathrm{Pb}$ & Low & - & Low & Low \\
\hline $\mathrm{Zn}$ & Low & - & - & Low \\
\hline
\end{tabular}

Individual concentrations of $\mathrm{Ca}, \mathrm{K}, \mathrm{Na}, \mathrm{Mg}, \mathrm{Al}$ and Fe influence the EDR of $\mathrm{Pb}$ and $\mathrm{Zn}$, suggesting that these two heavy metals are differently bound in the sediment than $\mathrm{Cd}$ and $\mathrm{Cu}$.

The initial concentrations of $\mathrm{Cu}, \mathrm{Pb}$ and $\mathrm{Zn}$ influence the model of $\mathrm{Cu}$, while having much lower influences on the remaining three models indicating that obtaining final concentrations of similar levels depend on initial pollution levels. The registered influence is thus related to the large variation in initial concentration levels rather than the heavy metals in themselves, and it could be anticipated that this would lead to discrepancies when using the model for predicting clean-up levels of new sediments.

It was, however, possible to extract trends and indications from the models that in addition were in line with previous findings. It was hence decided to test the model in order to assess whether the models at this point was liable for developing relevant remediation strategies for new sediments.

\subsection{Verification of the PLS model}

\subsubsection{Sediment selection}

In verifying the model it was important that the sediment properties of the new sediment as well as the experimental domain were comparable to the $\mathrm{X}$-matrix in the model. 
Selecting sediment for verification of the model was based on a PCA plot calculated from the sediment properties (figure 2). The sediments used in the PLS model(s) represent a large geographical span (Denmark, Norway, Greenland and USA) and are dispersed in three quadrants of the PCA scores plot (MOD_1-MOD_6 in figure 2) and hence display large dissimilarities in their properties. The dispersion of sediments sampled for this study from Hammerfest and Sisimiut illustrate that sediments from the same harbour do not necessarily exhibit the same variation in sediment properties and it may be necessary to apply different remediation strategies for different areas of a harbour.

The accompanying loadings plot (figure 3 ) illustrates which sediment properties have strong contributions to the variations in the scores plot. The most significant component ( $p 1$ ) contains all sediment properties not related to $\mathrm{pH}$ and carbonate content. Variables related to buffer capacity are expressed in the p2 dimension and have a strong influence on the initial (acidification) phase of the EDR treatment.

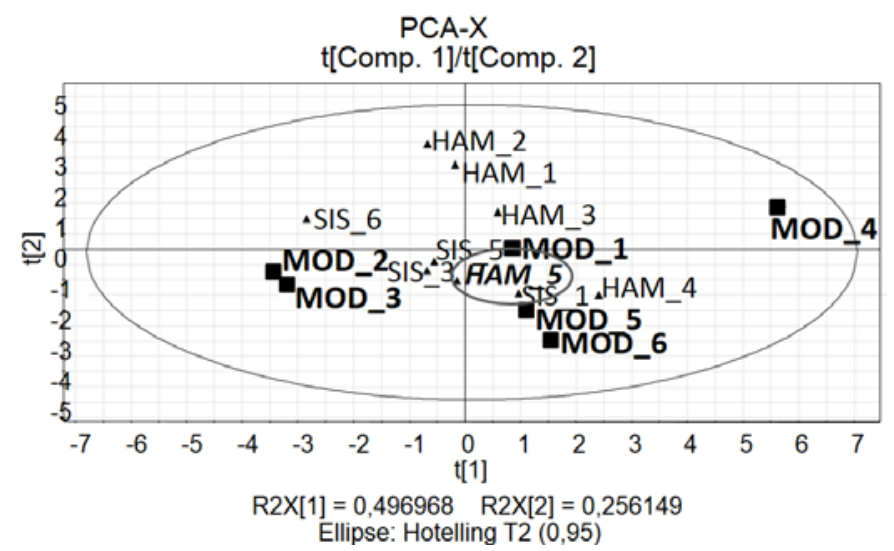

Figure 2: PCA plot of sediments applied in the PLS model (MOD) and sediments from Sisimiut (SIS) and Hammerfest (HAM).

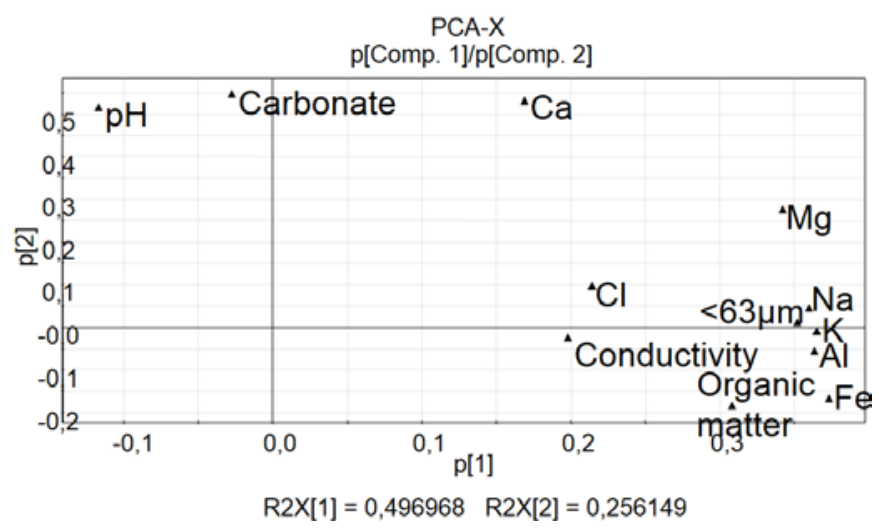

Figure 3: Loading plot.

A sediment located in the center of the PCA plot, i.e. HAM_5, was selected for testing the PLS model as it would represent a typical sample (table 5).

Table 5: Sediment properties for the sediments applied in the model and the Hammerfest sediment. Heavy metal concentrations are compared to OSPAR BC and Norwegian EPA criteria for sediments.

\begin{tabular}{|lllll|}
\hline Sediment Property & $\begin{array}{l}\text { Sediments in } \\
\text { model range }\end{array}$ & $\begin{array}{l}\text { Hammerfest } \\
\text { sediment }\end{array}$ & OSPAR BC & $\begin{array}{l}\text { Norwegian } \\
\text { EPA Class 1 }\end{array}$ \\
\hline
\end{tabular}




\begin{tabular}{|c|c|c|c|c|}
\hline Carbonate (\%) & {$[0.2-14]$} & $0.7 \pm 0.06$ & & \\
\hline Conductivity $(\mathrm{mS} / \mathrm{cm})$ & {$[1.6-25.7]$} & $12.3 \pm 1.18$ & & \\
\hline 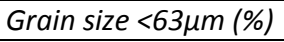 & {$[5-90]$} & 14.3 & & \\
\hline Organic matter (\%) & {$[3.7-26]$} & $5.3 \pm 0.08$ & & \\
\hline$p H$ & {$[6.7-8]$} & $7.5 \pm 0.02$ & & \\
\hline$A l(\mathrm{mg} / \mathrm{kg})$ & [2669-18472] & $7164 \pm 334$ & & \\
\hline $\mathrm{Fe}(\mathrm{mg} / \mathrm{kg})$ & [4406-24423] & $14244 \pm 214$ & & \\
\hline $\mathrm{Ca}(\mathrm{mg} / \mathrm{kg})$ & [3416-66750] & $5461 \pm 880$ & & \\
\hline$K(\mathrm{mg} / \mathrm{kg})$ & [747-7151] & $3037 \pm 65$ & & \\
\hline$M g(m g / k g)$ & [1198-11570] & $5102 \pm 103$ & & \\
\hline $\mathrm{Na}(\mathrm{mg} / \mathrm{kg})$ & [1170-22090] & $5882 \pm 509$ & & \\
\hline $\mathrm{Cl}(\mathrm{mg} / \mathrm{kg})$ & [448-33700] & $9224 \pm 836$ & & \\
\hline$C d(\mathrm{mg} / \mathrm{kg})$ & {$[0.55-16.6]$} & 0.14 & 0.20 & 0.25 \\
\hline $\mathrm{Cu}(\mathrm{mg} / \mathrm{kg})$ & [39-698] & $85 \pm 9$ & 5 & 35 \\
\hline $\mathrm{Pb}(\mathrm{mg} / \mathrm{kg})$ & [44-533] & $67 \pm 10$ & 25 & 30 \\
\hline$Z n(m g / k g)$ & [11-167] & $104 \pm 10$ & 50 & 150 \\
\hline
\end{tabular}

\subsubsection{Development of a sediment-specific remediation strategy}

The next step in model verification was to use the PLS model to develop a specific remediation strategy for the selected Hammerfest sediment. The concentrations of $\mathrm{Cu}$ and $\mathrm{Pb}$ both exceeded the Norwegian and OSPAR background levels, table 5.

The OSPAR BC criteria are based on a large geographical area and are fixed at more conservative values than the Norwegian EPA class 1 criteria. The Norwegian criteria, however, take into account the regional sediment conditions such as occurrence of igneous rocks. Since the Norwegian class 1 are targeted at Norwegian conditions it was decided to proceed with these criteria in developing the specific remediation test strategy for the Hammerfest sediment. Accordingly, the targeted heavy metals for remediation were $\mathrm{Cu}$ and $\mathrm{Pb}$.

The PLS model showed that the variables current density and remediation time had the highest comparative influence on the model and for this reason these variables were chosen for the remediation experiments. Contour plots for $\mathrm{Cu}$ and $\mathrm{Pb}$ were employed to show the concentration levels of heavy metal as a function of the chosen variables. The other experimental variables were held constant and the specific Hammerfest sediment properties (table 5) were employed.

Initial EDR experiments of the selected Hammerfest sediment revealed that operating at current densities above $0.52 \mathrm{~mA} / \mathrm{cm}^{2}$ resulted in undesirable disturbances to the system (high voltages; high energy consumption), so the maximum current density in the new experimental design was set at this value. The chosen minimum current density was $0.2 \mathrm{~mA} / \mathrm{cm}^{2}$ and the experiments were designed so that some would exceed the remediation objective while most would simply fulfil the governmental criteria. For the studied experimental settings, fluctuations in voltages were observed (3-47V) and the average voltages of the 5 experiments were in the range 4.7-16.6V. Average voltages below $10 \mathrm{~V}$ were registered in experiments 2 and 4 (shortest time), the other experiments had average voltages above $10 \mathrm{~V}$. 

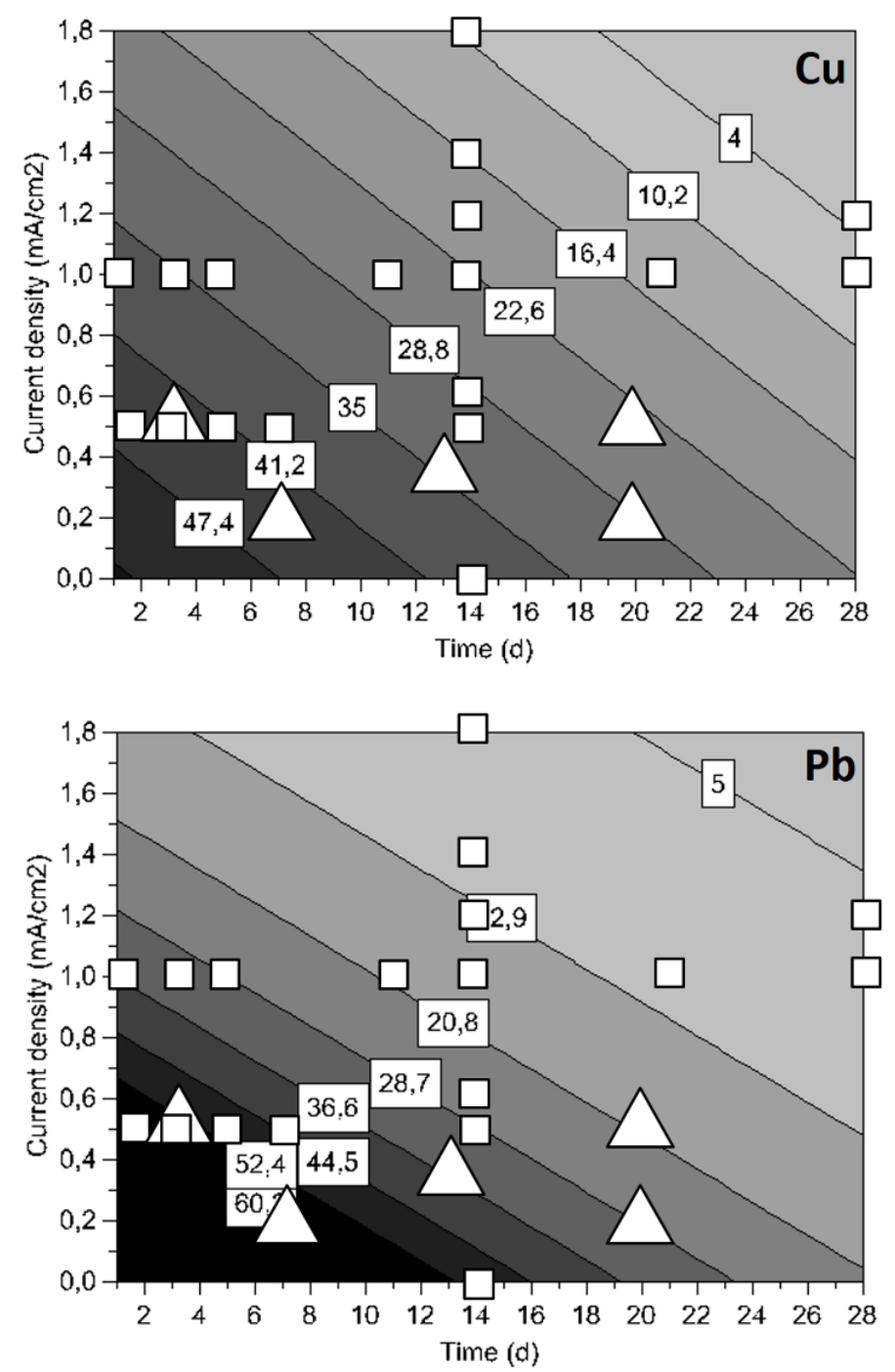

Figure 4: Contour plots of $\mathrm{Cu}$ (above) and $\mathrm{Pb}$ (below). Concentrations ( $\mathrm{mg} / \mathrm{kg}$ ) of the heavy metal (squares) as function of time and current density. The modelled experiments $(\square)$ and the experimental design $(\Delta)$ for the Hammerfest sediment are shown in the contour plots.

\subsubsection{Comparing results of the EDR experiments with the PLS model}

In the EDR experiments the removal efficiencies were in the range $17-82 \%$ for $\mathrm{Cu}$ and $26-87 \%$ for $\mathrm{Pb}$. The final concentrations of $\mathrm{Cu}$ and $\mathrm{Pb}$ in the 5 EDR experiments are all below the model predicted final concentrations (figure 5 and 6 ).

The lowest deviations from the models were observed in experiment 4, which could be explained by the vicinity of experiment 4 to model experiments with similar fixed experimental variables (figure 4) as well as similar variation in sediment properties of the model sediment used in those experiments (MOD_1 in the PCA scores plot in figure 2). This could imply that model predictions could be improved, by developing model(s) for sediments with similar variation in properties, or for each sediment, separately. 


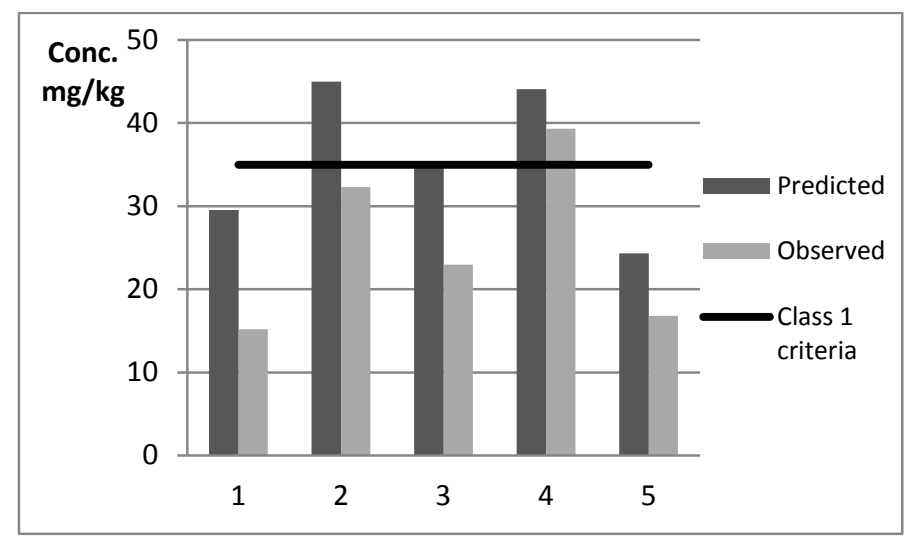

Figure 5: Final concentrations $(\mathrm{mg} / \mathrm{kg})$ of $\mathrm{Cu}$ in Hammerfest EDR experiments - predicted by model and observed in experiments.

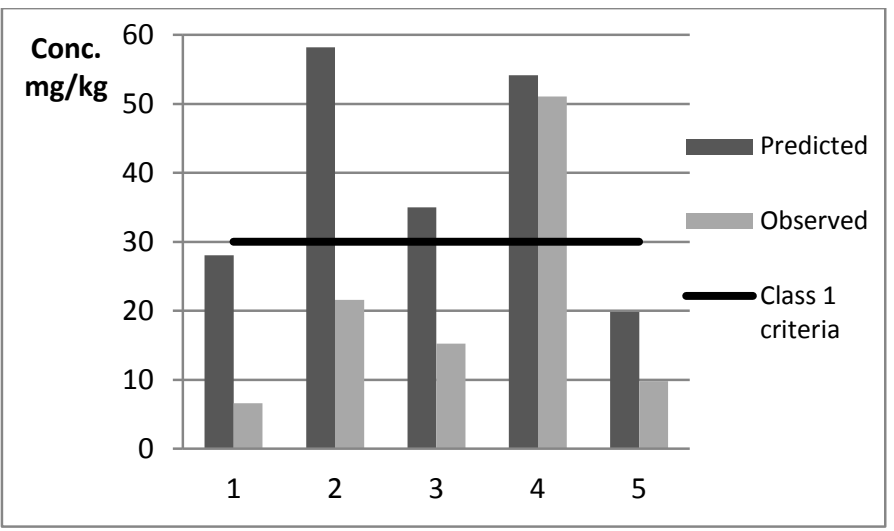

Figure 6: Final concentrations $(\mathrm{mg} / \mathrm{kg}$ ) of $\mathrm{Pb}$ in Hammerfest EDR experiments - predicted by model and observed in experiments.

The deviations between observed and predicted values are larger for $\mathrm{Pb}$ than $\mathrm{Cu}$, indicating that the model has a better fit for $\mathrm{Cu}$ within the studied experimental domain and sediments. This trend is further accentuated when inserting the results of the Hammerfest EDR experiments in the model plots of observed and predicted values in figure 7. The Hammerfest results are within the model deviations for $\mathrm{Cu}$, but do not fit as well for $\mathrm{Pb}$. This may be related to how the heavy metals are bound in the sediment. Since the removal of $\mathrm{Pb}$ is generally much higher than those predicted by the model, this may imply that a relatively higher fraction of $\mathrm{Pb}$ is related to the available fractions than was the case for the model sediments. Previous EDR studies of harbour sediments have shown that removal efficiencies of heavy metals is effected by how they are chemically bound in the sediment (exchangeable, reducible, oxidisable or residual fractions). Although removal from both the available and less available fractions were observed, relatively more was removed from the available fractions. So in order to achieve better predictions, data related to how metals are bound in the sediment may have to be included in the model calculations, or heavy metals and sediments may have to be modelled separately. 

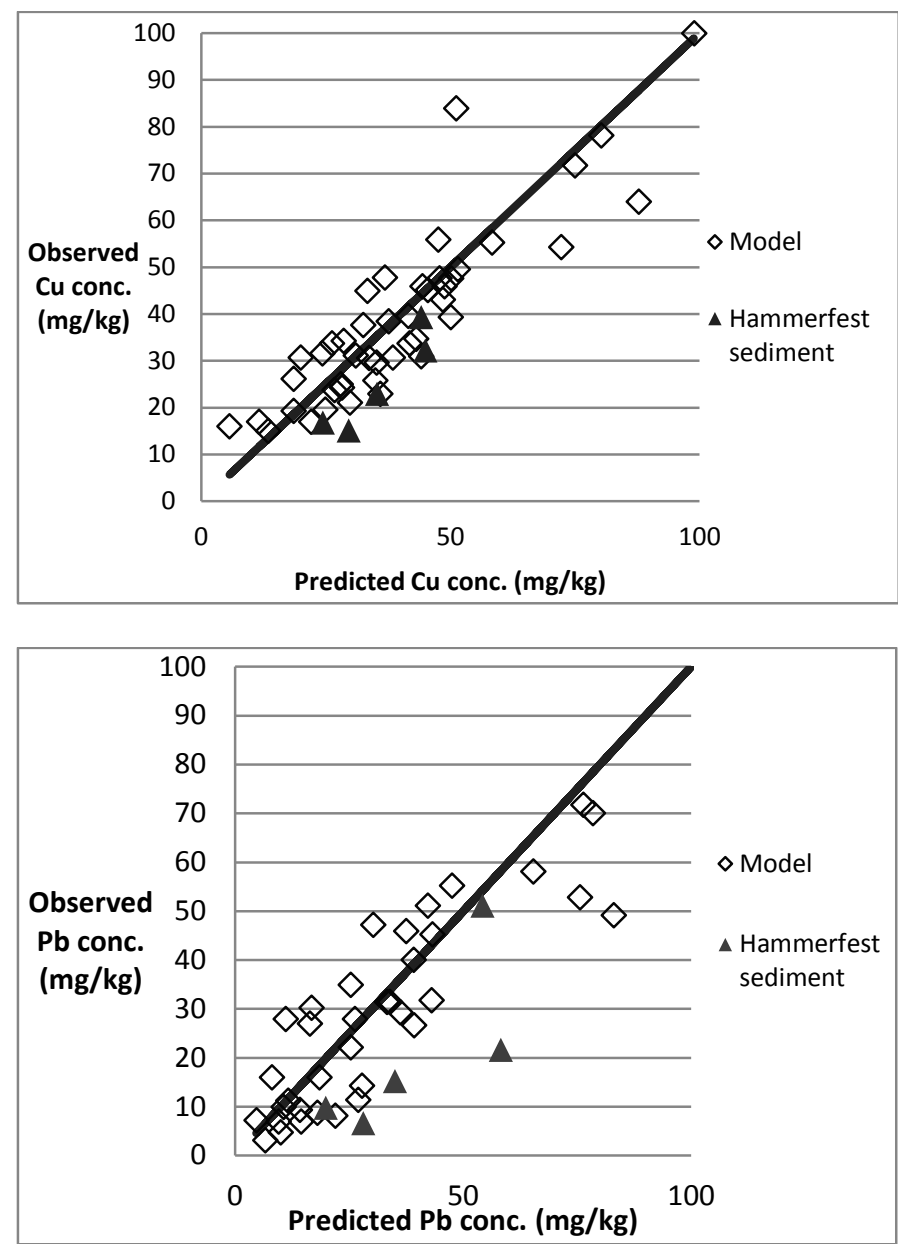

Figure 7: The final concentrations $(\mathrm{mg} / \mathrm{kg})$ of $\mathrm{Cu}$ and $\mathrm{Pb}$ in the Hammerfest sediment predicted by the model and observed after the EDR experiments compared to the predicted and observed values of the model sediments. The bold line represents the ideal scenario in which the predicted values equal the observed values.

Even though there were deviations between the values predicted by the model and experimentally found values of the Hammerfest sediment in this study, the PLS model was successfully used in establishing a good starting point for a remediation.

A new model based on the Hammerfest results was subsequently computed for the two targeted heavy metals, $\mathrm{Cu}$ and $\mathrm{Pb}$. The correlation factor, $\mathrm{R} 2 \mathrm{Y}$ was 0.85 and the predictive power, $\mathrm{Q} 2$ was 0.71 indicating a good and stable model. The VIP plot of the new model showed that the comparative importance of time (VIP value 1.34) was significantly larger than current density (VIP value 0.45), which could be due to the relatively narrow range of current density studied.

The contour plots of $\mathrm{Cu}$ and $\mathrm{Pb}$ (figure 8) further emphasise that the influence of time is comparatively more important than current density. The implication for subsequently developing a remediation strategy for the Hammerfest sediments is the possibility of operating at lower remediation times and higher current densities or at lower energy consumption levels (higher time and lower current densities). A future remediation strategy can hence be developed taking practical challenges into account; whether for instance time or energy consumption is essential for the remediation. 

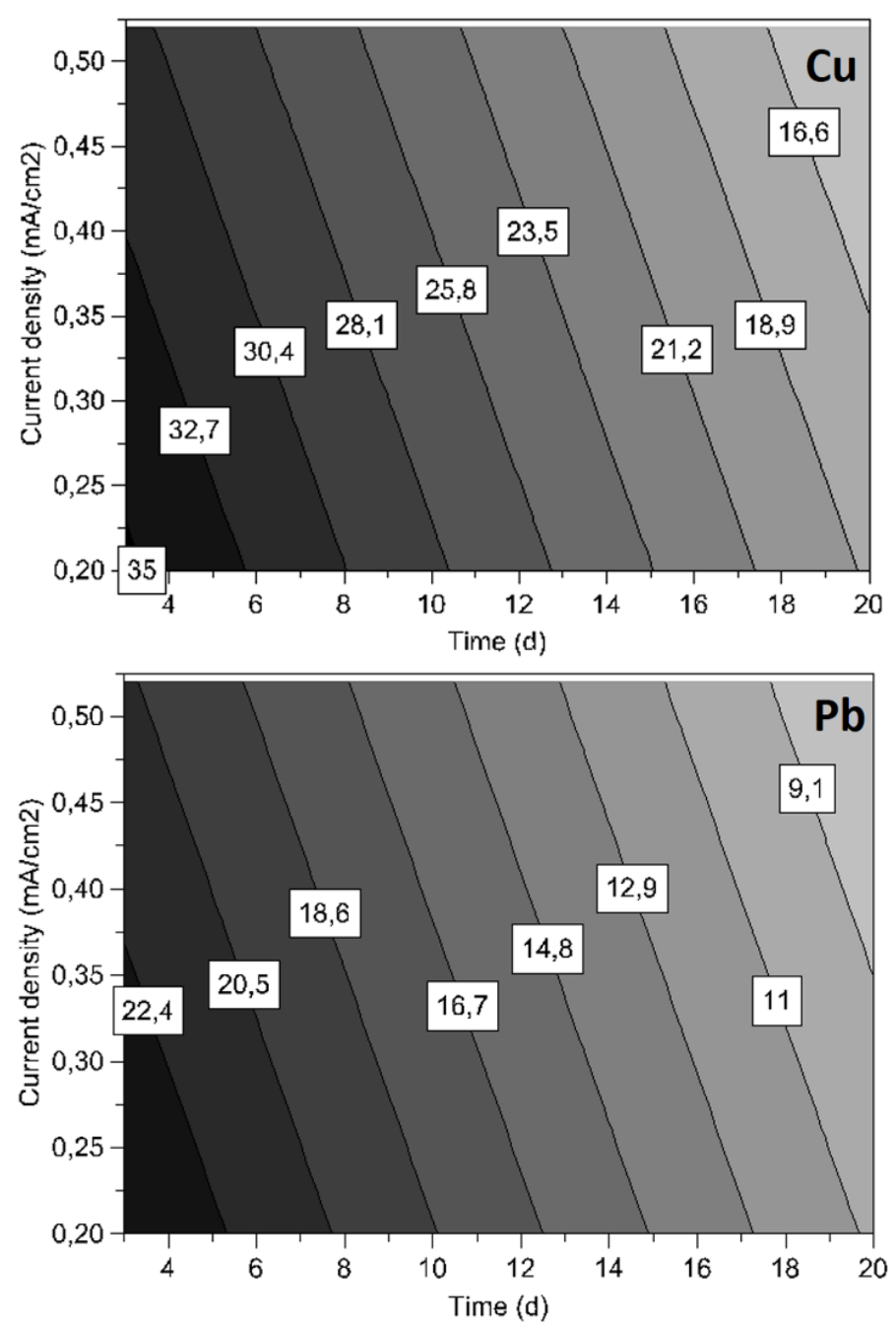

Figure 8: Contour plots of the $\mathrm{Cu}$ and $\mathrm{Pb}$ concentrations $(\mathrm{mg} / \mathrm{kg})$ as a function of time and current density, based on the results of the Hammerfest EDR experiments.

\section{Conclusions}

A PLS model based on 46 previous EDR experiments was developed to determine variable importance and depict clean-up levels a functions of experimental variables and sediment properties. The experimental variables current density and remediation time had the highest importance with VIP values $>1$. Models of each heavy metal $\mathrm{Cd}, \mathrm{Cu}, \mathrm{Pb}$ and $\mathrm{Zn}$ showed variances in the variable importance depending on the specific heavy metal, stressing the importance of how the given heavy metal is bound in the sediment.

The PLS model was used to make good estimations of potential clean-up levels of new sediment for which the targeted heavy metals were $\mathrm{Cu}$ and $\mathrm{Pb}$. In four of the five EDR experiments clean-up levels below background values of sediment as defined by the Norwegian EPA were met. The model predictions for both $\mathrm{Cu}$ and $\mathrm{Pb}$ were higher than the observed final concentrations in all of the five experiments. The results of $\mathrm{Cu}$ were within the model deviations, whereas results of $\mathrm{Pb}$ were only partly within the deviations of the model. The model was not based on multivariate design of experiments, so part of the experimental domain is not represented and in addition sediment properties are uncontrollable so they may not represent as large an area of the X-matrix as possible. Since the results were within the deviations of the model predictions, optimising model predictability 
would entail supplementing the existing experiments to ensure that as large a part of the X-matrix would be covered.

It may be necessary to assess whether the $\mathrm{X}$-matrix should be reduced, so that the optimization would entail developing several models covering different parts of the initial X-matrix, e.g. the PLS model based solely on the Hammerfest sediment, resulted in a better correlation factor and a more stable model. Another consideration is modelling the heavy metals separately - the results of this study indicated that variable importance as well as the potential for predicting clean-up levels varies depending on the heavy metal.

\section{Acknowledgements}

Hammerfest municipality is acknowledged for providing boat for sampling of sediments in Hammerfest. The Northern Environmental Waste Management (EWMA) project, which is funded by the Research Council of Norway through NORDSATSNING (grant number 195160) and Eni Norge AS, is acknowledged for funding.

\section{References}

[1] N.E. Agency, Environmental Reports of Remedial Actions in Norwegian Harbours (Norwegian), in, The Norwegian Environment Agency webpage, www.miljodirektoratet.no/no/Tema/Vann og hav/Forurenset:sjobunn/Opprydding-i-prioriterteområder, 2013.

[2] H.K. Hansen, L.M. Ottosen, B.K. Kliem, A. Villumsen, Electrodialytic remediation of soils polluted with $\mathrm{Cu}, \mathrm{Cr}, \mathrm{Hg}, \mathrm{Pb}$ and $\mathrm{Zn}$, J. Chem. Technol. Biotechnol., 70 (1997) 67-73.

[3] A.B. Ribeiro, E.P. Mateus, L.M. Ottosen, G. Bech-Nielsen, Electrodialytic Removal of Cu, Cr, and As from Chromated Copper Arsenate-Treated Timber Waste, Environ. Sci. Technol., 34 (2000) 784-788. [4] A.J. Pedersen, L.M. Ottosen, A. Villumsen, Electrodialytic removal of heavy metals from different fly ashes. Influence of heavy metal speciation in the ashes, J. Hazard. Mater., 100 (2003) 65-78. [5] L.M. Ottosen, A.J. Pedersen, H.K. Hansen, A.B. Ribeiro, Screening the possibility for removing cadmium and other heavy metals from wastewater sludge and bio-ashes by an electrodialytic method, Electrochim. Acta, 52 (2007) 3420-3426.

[6] G.M. Nystroem, L.M. Ottosen, A. Villumsen, Electrodialytic Removal of $\mathrm{Cu}, \mathrm{Zn}, \mathrm{Pb}$, and $\mathrm{Cd}$ from Harbor Sediment: Influence of Changing Experimental Conditions, Environ. Sci. Technol., 39 (2005) 2906-2911.

[7] Y.B. Acar, A.N. Alshawabkeh, Principles of electrokinetic remediation, Environ. Sci. Technol., 27 (1993) 2638-2647.

[8] Y.B. Acar, R.J. Gale, A.N. Alshawabkeh, R.E. Marks, S. Puppala, M. Bricka, R. Parker, Electrokinetic remediation: Basics and technology status, J. Hazard. Mater., 40 (1995) 117-137.

[9] A.N. Alshawabkeh, Electrokinetic soil remediation: challenges and opportunities, Sep. Sci. Technol., 44 (2009) 2171-2187.

[10] L.M. Ottosen, H.K. Hansen, C.B. Hansen, Water splitting at ion-exchange membranes and potential differences in soil during electrodialytic soil remediation, J Appl Electrochem, 30 (2000) 1199-1207.

[11] G.M. Nystrom, L.M. Ottosen, A. Villumsen, The use of sequential extraction to evaluate the remediation potential of heavy metals from contaminated harbour sediment, J Phys Iv, 107 (2003) 975-978. 
[12] G.M. Nystroem, L.M. Ottosen, A. Villumsen, Acidification of harbor sediment and removal of heavy metals induced by water splitting in electrodialytic remediation, Separ Sci Technol, 40 (2005) 2245-2264.

[13] G.M. Nystroem, L.M. Ottosen, A. Villumsen, Electrodialytic removal of $\mathrm{Cu}, \mathrm{Zn}, \mathrm{Pb}$, and $\mathrm{Cd}$ from harbor sediment: Influence of changing experimental conditions, Environ Sci Technol, 39 (2005) 2906-2911.

[14] G.M. Nystrom, L.M. Ottosen, A. Villumsen, Test of experimental set-ups for electrodialytic removal of $\mathrm{Cu}, \mathrm{Zn}, \mathrm{Pb}$ and $\mathrm{Cd}$ from different contaminated harbour sediments, Eng Geol, 77 (2005) 349-357.

[15] G.M. Nystroem, A.J. Pedersen, L.M. Ottosen, A. Villumsen, The use of desorbing agents in electrodialytic remediation of harbour sediment, Sci Total Environ, 357 (2006) 25-37.

[16] K.H. Gardner, G.M. Nystroem, D.A. Aulisio, Leaching properties of estuarine harbor sediment before and after electrodialytic remediation, Environ Eng Sci, 24 (2007) 424-433.

[17] L.M. Ottosen, G.M. Nystrom, P.E. Jensen, A. Villumsen, Electrodialytic extraction of Cd and Cu from sediment from Sisimiut Harbour, Greenland, J Hazard Mater, 140 (2007) 271-279.

[18] G.M. Kirkelund, L.M. Ottosen, A. Villumsen, Electrodialytic remediation of harbour sediment in suspension-Evaluation of effects induced by changes in stirring velocity and current density on heavy metal removal and pH, J Hazard Mater, 169 (2009) 685-690.

[19] G.M. Kirkelund, L.M. Ottosen, A. Villumsen, Investigations of $\mathrm{Cu}, \mathrm{Pb}$ and $\mathrm{Zn}$ partitioning by sequential extraction in harbour sediments after electrodialytic remediation, Chemosphere, 79 (2010) 997-1002.

[20] G.M. Nystroem, Electrodialytic removal of heavy metals from contaminated harbour sediments, in: Department of Civil Engineering, DTU, Lyngby, 2004.

[21] J.M. Paz-Garcia, K. Baek, I.D. Alshawabkeh, A.N. Alshawabkeh, A generalized model for transport of contaminants in soil by electric fields, Journal of Environmental Science and Health, Part A, 47 (2012) 308-318.

[22] J.M. Paz-García, B. Johannesson, L.M. Ottosen, A.N. Alshawabkeh, A.B. Ribeiro, J.M. RodríguezMaroto, Modeling of electrokinetic desalination of bricks, Electrochim Acta, 86 (2012) 213-222.

[23] A.T. Lima, A.B. Ribeiro, J.M. Rodriguez-Maroto, E.P. Mateus, A.M. Castro, L.M. Ottosen, Experimental and modeling of the electrodialytic and dialytic treatment of a fly ash containing $\mathrm{Cd}, \mathrm{Cu}$ and $\mathrm{Pb}$, J Appl Electrochem, 40 (2010) 1689-1697.

[24] Y.B. Acar, A.N. Alshawabkeh, Principles of Electrokinetic Remediation, Environ Sci Technol, 27 (1993) 2638-+.

[25] R. Calson, J.E. Carlson, Design and Optimisation in Organic Synthesis, 2 ed., Elsevier, 2005.

[26] F.A. Jan, M. Ishaq, I. Ihsanullah, S.M. Asim, Multivariate statistical analysis of heavy metals pollution in industrial area and its comparison with relatively less polluted area: A case study from the City of Peshawar and district Dir Lower, J Hazard Mater, 176 (2010) 609-616.

[27] I. Cheng, J. Lu, X. Song, Studies of potential sources that contributed to atmospheric mercury in Toronto, Canada, Atmospheric Environment, 43 (2009) 6145-6158.

[28] G. De Luca, A. Furesi, R. Leardi, G. Micera, A. Panzanelli, P. Costantina Piu, G. Sanna, Polycyclic aromatic hydrocarbons assessment in the sediments of the Porto Torres Harbor (Northern Sardinia, Italy), Marine Chemistry, 86 (2004) 15-32.

[29] A.V. Filgueiras, I. Lavilla, C. Bendicho, Evaluation of distribution, mobility and binding behaviour of heavy metals in surficial sediments of Louro River (Galicia, Spain) using chemometric analysis: a case study, Sci Total Environ, 330 (2004) 115-129.

[30] S. Wold, M. Sjöström, L. Eriksson, PLS-regression: a basic tool of chemometrics, Chemometrics and Intelligent Laboratory Systems, 58 (2001) 109-130.

[31] J. Trygg, S. Wold, Orthogonal projections to latent structures (O-PLS), Journal of Chemometrics, 16 (2002) 119-128.

[32] H. Abdi, Partial least squares regression and projection on latent structure regression (PLS Regression), in, John Wiley \& Sons, 2010. 
[33] K.P. Singh, A. Malik, V.K. Singh, D. Mohan, S. Sinha, Chemometric analysis of groundwater quality data of alluvial aquifer of Gangetic plain, North India, Anal Chim Acta, 550 (2005) 82-91.

[34] S. Jansson, H. Antti, S. Marklund, M. Tysklind, Multivariate Relationships between Molecular Descriptors and Isomer Distribution Patterns of PCDD/Fs Formed during MSW Combustion, Environ Sci Technol, 43 (2009) 7032-7038.

[35] S.R. Stephens, B.J. Alloway, A. Parker, J.E. Carter, M.E. Hodson, Changes in the leachability of metals from dredged canal sediments during drying and oxidation, Environ Pollut, 114 (2001) 407413. 